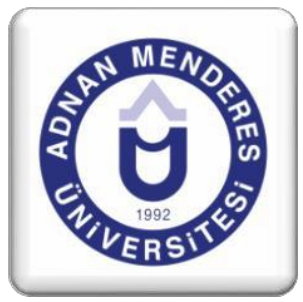

\title{
Fen Bilgisi Öğretmen Adaylarının Genel Kimya Laboratuvar Çevresine Yönelik Algılarının İncelenmesi ${ }^{3}$
}

\author{
Aysun CEYLAN ${ }^{1}$, Burak FEYZIOĞLU ${ }^{2}$
}

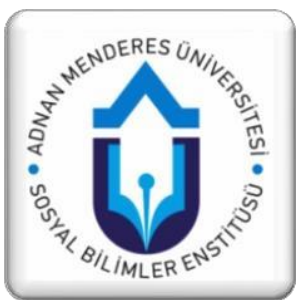

Özet

Çalışmanın amacı Fen Bilgisi öğretmen adaylarının Genel Kimya Laboratuvar çevresine yönelik algılarını yakınlık, açık uçluluk, bütünleşme, kurallarda netlik ve fiziksel ortam boyutlarına göre incelemektir. Tarama araştırma türlerinden kesitsel tarama modelinin kullanıldığı bu araştırmanın örneklemini Türkiye'nin farklı bölgelerinde yer alan 10 üniversitede öğrenim gören 557 Fen Bilgisi 1.sınıf öğretmen adayı oluşturmaktadır. Adayların laboratuvar algıları belirlenirken Genel Kimya Laboratuvarı Sınıf Çevre Ölçeği kullanılmıştır. Öğretmen adaylarının algılarının her bir boyuttaki dağılımı, bu dağılımın bulundukları üniversiteye göre ve dersi veren öğretim elemanının uzmanlık alanına göre farklılık gösterip göstermediği incelenmiştir. Laboratuvar algılarındaki dağılım frekans ve yüzde değerleri ile sunulurken dağılımdaki farklılık Kruskal-Wallis, Bağımsız örneklemde $t$ testi ve Mann-Whitney $U$ testleriyle analiz edilmiştir. Laboratuvar algısı öğretmen adaylarının her boyutta bulundukları üniversiteye göre anlamlı farklılık gösterirken, dersi veren öğretim elemanının uzmanlık alanına göre sadece açık uçluluk ve bütünleşme boyutlarında farklılık göstermiş̧ir. Elde edilen bulgular alanyazınla ilişkilendirilerek tartışılmış ve önerilerde bulunulmuştur.

Anahtar Kelimeler: Genel Kimya Laboratuvarı Sınıf Çevre Ölçeği, Yakınlık, Açık Uçluluk, Bütünleşme, Kurallarda Netlik, Fiziksel Ortam

\section{Examining Science Pre-teachers' Perceptions of General Chemistry Laboratory Environment}

\begin{abstract}
The purpose of this research was to examine science pre-teachers' perceptions of general chemistry laboratory environment on dimensions of student-cohesiveness, open-endedness, integration, rule-clarity, and materialenvironment. The sample group of this research which was conducted according to the cross-sectional model as one of the survey-research models, consists of 557 science pre-teachers who were studying their $1^{\text {st }}$ year in 10 different universities around Turkey. General Chemistry Laboratory Class Environment Perception Scale was used to designate the pre-teachers' perceptions of laboratory. In addition to the distribution of pre-teachers' perceptions in each dimension, it was also examined whether the distribution differs based on the universities in which those pre-teachers study, and the lecturing instructors' areas of expertise. The distribution in their perceptions was indicated by frequency and percentage values, and the difference in the distribution was analyzed by Kruskal-Wallis, Independent Samples T Test and Mann-Whitney U test. While in perceptions of laboratory there was a significant difference in each dimension based on the universities the pre-teachers are studying in, there was a difference in only dimensions of open-endedness and integration based on the lecturing instructors' areas of expertise. The acquired findings were related to the Literature, discussed and some suggestions were made.
\end{abstract}

\footnotetext{
1. Yüksek Lisans, Adnan Menderes Üniversitesi, Fen Bilimleri Enstitüsü, Fen Bilgisi Eğitimi, Aysunceylan09@gmail.com

2. Dr. Öğr. Üyesi, Adnan Menderes Üniversitesi, Eğitim Fakültesi, Kimya Eğitimi, bfeyzioglu@ adu.edu.tr

3. Bu çalışmanın bir bölümü, 7-9 Eylül 2017 tarihleri arasında Fırat Üniversitesi Eğitim Fakültesi’nde düzenlenen

V. Ulusal Kimya Eğitimi Kongresi'nde sözlü bildiri olarak sunulmuştur.
} 
Keywords: General Chemistry Laboratory Classroom Environment Scale, Student Cohesivennes, OpenEndedness, Integration, Rule-Clarity, Material Environment

\section{Giriş}

Bandura (1986) inançların karar vermede en iyi gösterge olduğunu belirtmiştir. Bu durumda inançların temelini o duruma ilişkin algılar belirler. Kimya eğitimi açısından bakıldığında laboratuvar uygulamaları ve bu uygulamalara ilişkin algılarda önemlidir. Çünkü bu algılar Kimya eğitiminin tamamlayıcısı ve önemli bir kısmını oluşturan laboratuvar uygulamalarının niteliğini etkiler. Okullarda laboratuvar uygulamalarını etkin hale getirebilmek için öğretmen adaylarının laboratuvara yönelik olumsuz algılarını belirlemek ve gerekirse değiştirmek gerekir. Literatürde öğretmen ve öğretmen adaylarının laboratuvara yönelik algılarında, laboratuvar uygulamalarının yeterince ve etkili olarak uygulanmaması (Çallıca, Erol, Kavcar ve Sezgin, 2001; Böyük, Demir ve Erol, 2010), değerlendirme sisteminin ve Kimya programının uygulamalara uzak olması, laboratuvar uygulamalarının öğrenci merkezli değil de geleneksel yöntemlerle yapılması (Çallıca vd., 2001), ders programlarında laboratuvar uygulamalarının düşünülmeden planlanması ve ders sürelerindeki yetersizlikler (Booth, 2001) belirleyici faktörlerdendir. Algıları belirleyen diğer faktörler, etkili ve yeterli miktarda ders materyalinin bulunmaması, öğrencilerin hazırbulunuşluklarındaki yetersizliği (Hofstein ve Lunetta, 1982), sinıfların kalabalık olması (Cheung, 2008), laboratuvar ortamında yeterince güvenlik önleminin alınamaması (Deters, 2005; Böyük vd., 2010) laboratuvara yönelik algıları etkilemektedir. $\mathrm{Bu}$ sorunları iyileştirmek ve okullarda laboratuvar uygulamalarını etkin hale getirmek gerekmektedir. Bu sebeple öğretmen ve öğretmen adaylarının laboratuvara yönelik algıları belirli dönemlerde tespit edilmelidir.

Genel Kimya laboratuvarına yönelik algılar birçok alt boyuttan oluşmaktadır. Bu çalışmada, Fen Bilgisi öğretmen adaylarının Genel Kimya laboratuvarına yönelik algıları Moos ve Trickett (1987) tarafından oluşturulan yakınlık (student cohesivennes), açık uçluluk (openendedness), bütünleşme (integration), kurallarda netlik (rule-clarity) ve fiziksel ortam (material environment) boyutlarıyla incelenmiştir. Yakınlık, öğrencilerin birbirlerini tanıma, birbirlerine yardım etme ve birbirlerini destekleme derecesidir. Açık uçluluk, her öğrencinin aynı deneyleri yapmaya zorlanmaması, her öğrenciye istediğinde farklı deney yapabilme şansını tanıma derecesidir. Bütünleşme, laboratuvardaki etkinliklerin teorik derslerdeki konularla bütünleşme derecesidir. Kurallarda netlik, laboratuvarda çalışma kurallarının açıklığı ve formal olarak belirlenme derecesidir. Laboratuvardaki davranışlara bu kurallar yön verecektir. Fiziksel ortam, laboratuvarın fiziki altyapısı, içerisinde bulunan araç ve gereç sayısı ve diğer materyallerin amaca uygunluk derecesidir.

Laboratuvar ortamında istenilen becerilerin ve kavramların ediniminde öğrenme çevresinin rolünü de dikkate almak gerekir. Entwistle (1998) öğrencilerin öğrenmesini analiz etmede öğrenme ortamı hakkındaki öğrencilerin algılarını dikkate almayı önemle vurgulamıştır. Her sınıfta özel bir öğrenme çevresi bulunur ve sınıftaki tüm öğrenciler bu çevreden az ya da çok etkilenir. Bilişsel kuramcılar öğrenmeyi hemen hemen soyut bir eylem olarak tarif etmişler ve fiziksel ve sosyal şartların etkisini göz ardı etmişlerdir (Atasoy, 2004, s.72). Ancak okul, sinıf, laboratuvar gibi ortamlar ve bu ortamların sicaklık, gürültü, sinıf mevcudu, malzemelerin yeterliliği, oturma düzeni de öğrenme üzerinde dikkate alınmalıdır. Benzer şekilde sınıftaki kurallar, öğretmen-öğrenci ve öğrenci-öğrenci ilişkisi, derse katılım isteği gibi etmenler öğrenmeyi etkileyen faktörlerdendir (Kingir, Tas, Gok ve Vural, 2013). Fraser 
(1994) tarafından sınıftaki öğrenme çevresi değişkenleri ile öğrencilerin bilişsel ve duyuşsal öğrenme ürünleri arasında kuvvetli bağlar bulunduğu ileri sürülmüştür. Diğer taraftan Haertel, Waldberg ve Haertel (1981)'de öğrencilerin sınıf öğrenme çevresi algıları ile öğrenme ürünleri arasında kuvvetli ilişkiler bulunduğunu belirtmiştir. Bu durumda sınıfta etkili bir öğrenme çevresi yaratılmasının, öğrencilerin bilişsel ve duyuşsal öğrenme ürünleri üzerinde olumlu bir etkide bulunabileceği ileri sürülebilir (Doğan, Atılgan ve Demirci, 2003).

Öğrencilerin problemi belirlerken, problemi çözmek için araştırmayı tasarlarken, deney yaparken ve yaptıkları deneyi açıklarken bilinçleri öğrenme çevresiyle sürekli etkileşim halindedir. Öğrenme çevresini akranları, öğretmeni, fiziksel ortam ve bu ortamdaki etkileşimler oluşturur. Kimya eğitiminin hedefine ulaşmasında çağdaş öğrenme yaklaşımları çerçevesinde yaparak-yaşayarak öğrenmeyi temel alan ve öğrenme çevresindeki etkileşimleri dikkate alan laboratuvar uygulamaları son derece önemlidir (Hofstein, Levi-Nahum ve Shore, 2001). Laboratuvarlar konuların öğrenciye yaptırılarak, denenerek veya gösterilerek öğretilmesi ve kontrol edilebilir bir ortam olması açısından bilginin kullanıldığı, problemin tanımlandığı, el becerileri ve işlem yeteneklerinin geliştirildiği, soyut algılamaları zihinde somutlaştırılarak anlam kazandığı, elde edilen bilgilerin yaşamsal değere sahip olduğunun anlaşıldığ1 ortamlardır (Güneş, Şener, Germi ve Can, 2013). Öğrencilerin, derslerde gördükleri soyut kavramları somutlaştırılması ve bu kavramların daha anlaşı1ır hale getirilebilmesi açısından laboratuvarlar önemlidir (Hofstein ve Lunetta, 1982; Lunetta, 1998; Chin, Kozma, Marx ve Russell, 2000; Hofstein vd., 2001). Laboratuvarın önemi öğrenme ortamında etkili kullanılmasıyla artar. Etkili kullanılması da yapılan deneyin açıklık düzeyi ve laboratuvar yaklaşımıyla ilişkilidir. Buck, Bretz ve Towns (2008), laboratuvarın açıklık düzeyini doğrulama, yapılandırılmış sorgulama, rehberli sorgulama, açık sorgulama ve otantik sorgulama olarak sınıflandırmıştır. Doğrulama düzeyinde problem/soru, teori/tahmin, yöntemler/model, sonuçların analizi, sonuçların iletişimi ve sonuçlar öğretmen tarafindan verilir. Yapılandırılmış sorgulamada öğretmen tarafından sadece sonuçlar verilmez. Rehberli sorgulamada, öğretmen tarafından sonuçların iletişimi ve sonuçlar verilmez. Açık sorgulamada, problem/soru ve teori/tahmin verilir. Otantik sorgulamada, problem/soru, teori/tahmin, yöntemler/model, sonuçların analizi, sonuçların iletişimi ve sonuçların hiçbiri verilmez, bunlar öğrencinin tasarımına bırakılmıştır. Gerçek yaşam durumlarının sınıf ortamına taşınarak öğrenenlerin etkinlikler yoluyla gerçek yaşam durumları ile etkileşimlerini sağlaması bütünleşme ile ilgilidir (Hein, 1991; Uçar ve Yeşilyaprak, 2006). Domin (2007)'de laboratuvar yaklaşımını tümevarım ve tümdengelim olarak sınıflandırmıştır. Tümdengelim (doğrulama) yaklaşımında, laboratuvar kılavuz kitapları ya da öğretmenler, deneyin işlem basamaklarına ve verilerin nasıl toplanıp, ne şekilde analiz edileceğine dair ayrıntılı açıklamalar yapar. Deneylerden elde edilen sonuçlar, gerçekleşmesi beklenen sonuçlar ile karşılaştırılır. Kısacası bilginin tamamı öğretmen tarafından verilir ve öğrencilerin tüm eylemleri yönlendirilir. Böyle bir durumda öğrenciler bağımsız düşünemezler (Kanl1, 2007). Laboratuvar çalışmalarıyla öğrenciler, ilke, kavram veya bilimsel genellemeleri bizzat kendileri bulmaya çalışır; sonuçlar sınıf ortamında tartışmaya açılır ve öğrencilere araştırılan konuyla ilgili bilimsel bilgiler verilerek konunun öğrenilmesi sağlanır. Öğrenci deney sonunda hangi sonuca ulaşacağını önceden bilmemektedir ve deneyin yapılması, verilerin toplanması ve yorumlanması öğrencilere bırakılır. Deneyde kullanılacak araç-gereçler ise öğretmen tarafından belirlenir ve temini sağlanır (Ayas, 1998). Öğretim sürecinde yer alan kavramlar günlük yaşamla ilişkilendirilebildiği oranda kalıcı olmakta ve hayat boyu karşılaşılan yeni durumlara daha kolay uygulanabilmektedir (Coştu, Ünal ve Ayas, 2007). Yani, laboratuvar etkinliklerinin Genel Kimya dersinde işlenen konularla ilişkili olduğunu ve öğrencilerin kavramları iyi anlaması gerektiğini 
göstermektedir. $\mathrm{Bu}$ nedenle öğretmen adayları laboratuvar kullanımı konusunda yeteri kadar bilgiye sahip olmaları ile yapıcı, yaratıcı, eleştirel ve analitik düşünme yeteneğine, güvenli bir laboratuvar ortamı hazırlayabilme bilgi ve becerisine sahip olabilmelidirler (Ayas, Akdeniz ve Çepni, 1994).

\section{1. Çalışmanın Önemi}

Yenilenen öğretim programı sorgulamaya dayalı öğrenme yaklaşımını benimsemektedir. $\mathrm{Bu}$ durumda öğretmenlerden sorgulama düzeyinin yüksek olduğu deneylerin yapılması beklenmektedir. Laboratuvar ortaminda istenilen becerilerin ve kavramların ediniminde öğrenme çevresinin fiziksel ve sosyal şartlarının etkisini göz önünde bulundurarak okul, sınıf, laboratuvar gibi ortamlar ve bu ortamların sicaklık, gürültü, sinıf mevcudu, malzemelerin yeterliliği, oturma düzeni de öğrenme üzerinde dikkate alınmalıdır. Benzer şekilde sınıftaki kurallar, öğretmen-öğrenci ve öğrenci-öğrenci ilişkisi, derse katılım isteği gibi etmenler öğrenmeyi etkileyen faktörlerdendir (Kingir vd., 2013).

Öğretmen adaylarının laboratuvar ortamına yönelik algılarının istenilen yönde değiştirilmesinde üniversite öncesinde ve üniversitede geçirdikleri öğretim yaşantılarının önemli etkisi bulunmaktadır. Üniversitedeki öğretim yaşantılarının belirlenmesi istenilen hedefte öğretmen yetiştirilip yetiştirememe konusunda eğitimcilere bilgi verebilir. Öğretmen adaylarının laboratuvar algıları belirlenebilirse laboratuvarlar buna göre düzenlenebilir.

\subsection{Araştırmanın Amacı}

Çalışmanın amaçlarından birincisi, Fen Bilgisi öğretmen adaylarının Genel Kimya Laboratuvar çevresine yönelik algılarını yakınlık, açık uçluluk, bütünleşme, kurallarda netlik ve fiziksel ortam boyutları açısından incelemektir. İkinci amac1, Türkiye'de bulunan 10 farklı devlet üniversitesinde öğrenim gören Fen Bilgisi öğretmen adaylarının laboratuvar algılarında üniversiteler arasında yakınlık, açık uçluluk, bütünleşme, kurallarda netlik ve fiziksel ortam boyutları açısından farklılığın olup olmadığını araştırmaktır. Üçüncü amacı ise, Fen Bilgisi öğretmen adaylarının Genel Kimya Laboratuvar çevresine yönelik algılarında laboratuvar dersini veren öğretim elemanının Kimya ve Kimya/Fen Eğitimi uzmanlık alanına göre anlamlı farklılığın olup olmadığını incelemektir.

Çalışmanın amaçlarına uygun olarak problem cümleleri aşağıda ifade edilmiştir.

\subsection{Araştırmanın Problemi}

1. Fen Bilgisi öğretmen adaylarının Genel Kimya Laboratuvar çevresine yönelik algılarının yakınlık, açık uçluluk, bütünleşme, kurallarda netlik ve fiziksel ortam boyutları açısından durumu nedir?

2. Türkiye'de bulunan 10 farklı devlet üniversitesinde öğrenim gören Fen Bilgisi öğretmen adaylarının Genel Kimya Laboratuvar çevresine yönelik algılarında üniversiteler arasında yakınlık, açık uçluluk, bütünleşme, kurallarda netlik ve fiziksel ortam boyutları açısından farklılık var midır? 
3. Fen Bilgisi öğretmen adaylarının Genel Kimya Laboratuvar çevresine yönelik algılarında laboratuvar dersini veren öğretim elemanının Kimya ve Kimya/Fen Eğitimi uzmanlık alanına göre anlamlı farklılık var mıdır?

\section{Yöntem}

Tarama araştırmasının türlerinden olan kesitsel tarama kullanılmıştır. Kesitsel tarama, veri toplama sürecinin bir seferde gerçekleştirildiği tarama türüdür (Fraenkel ve Wallen, 2000).

\subsection{Evren-Örneklem}

Araştırmanın evreni, 2016-2017 öğretim y1lı bahar döneminde Türkiye'de bulunan Fen Bilgisi Öğretmenliği programında okuyan 1. sınıf öğretmen adaylarıdır. Evren büyüklüğü, 2017 Öğrenci Seçme ve Yerleştirme Merkezi'nin tercih k1lavuzunda yer alan kontenjanlardan hesaplanmıştır. Örneklem büyüklüğü aşağıda gösterilen sürekli değiş̧ken formülüyle hesaplanır.

$$
\mathrm{n}=\frac{n o}{1+\mathrm{no} / \mathrm{N}} \quad \mathrm{n}_{\mathrm{o}}=(\mathrm{t} \mathrm{x})_{\mathrm{S}) / \mathrm{d}^{2}} \quad \mathrm{n}_{\mathrm{o}} / \mathrm{N}<0.5
$$

$\mathrm{N}$ : Evren büyüklüğ̈̈=4280, t: güven düzeyine karş1lı gelen tablo değeri=1.96, d: Tahmini tolerans (sapma) miktarı $=0.05$, S: Evren için tahmin edilen standart sapma $=0.5, \mathrm{n}=$ Örneklem büyüklüğü değerleri formülde yerine koyulduğunda $n_{0}=384.16, n=352.54$ bulunmaktadır. Dolayısıyla örneklem büyüklüğü 353 öğretmen adayı olarak alınabilir. Türkiye'de 68 devlet üniversitesinde Fen Bilgisi Öğretmenliği programında eğitim verilmektedir. Çalışmada, Türkiye'nin farklı bölgelerinde yer alan 10 devlet üniversitesine ulaşılabilmiştir. Bu üniversitelerde toplam 660 öğrenci bulunmaktadır. Çalışma 557 birinci sınıf öğretmen adayı ile gerçekleşmiştir. Bu örneklem grubuyla evrenin \% 13'üne ulaşılmıştır. Örneklem, seçkisiz olmayan örnekleme yöntemlerinden uygun/amaçlı örnekleme yöntemiyle belirlenmiştir. Tablo 1' de örneklemde bulunan üniversitelere göre Genel Kimya Laboratuvar dersini veren öğretim görevlisinin uzmanlık alanı (Doktora programı) ve öğretmen adaylarının toplam frekansı verilmiştir.

Tablo 1. Üniversitelerde Genel Kimya Laboratuvar Dersini Veren Öğretim Görevlisinin Uzmanlık Alanı (Doktora Programı) ve Öğretmen Adaylarının Toplam Frekansı

\begin{tabular}{lll}
\hline Üniversite Adı & $\begin{array}{l}\text { Öğretim Görevlisinin Doktora } \\
\text { Programı }\end{array}$ & $\begin{array}{l}\text { Öğretmen Adaylarının Toplam } \\
\text { Frekansı } \\
\text { fn }\end{array}$ \\
\hline Ü1 & Kimya Eğitimi & 48 \\
\hline Ü2 & Kimya & 33 \\
\hline Ü3 & Kimya & 49 \\
\hline$\ddot{\mathbf{U}} \mathbf{3}$ & Kimya Eğitimi & 59 \\
\hline Ü5 & Kimya & 64 \\
\hline Ü6 & Fen Bilgisi Eğitimi & 86 \\
\hline Ü7 & Kimya & 76 \\
\hline
\end{tabular}




\begin{tabular}{lll}
\hline Ü8 & Fen Bilgisi Eğitimi & 24 \\
\hline Ü9 & Fen Bilgisi Eğitimi & 44 \\
\hline Ü10 & Kimya & 74 \\
\hline
\end{tabular}

\subsection{Veri toplama aracı}

Araştırmada, 10 devlet üniversitesindeki öğretmen adaylarına Genel Kimya Laboratuvarı Sınıf Çevre Ölçeği uygulanmıştır.

\section{Genel Kimya Laboratuvarı Sınıf Çevre Ölçeği}

Fen Bilgisi öğretmen adaylarının Genel Kimya laboratuvar uygulamalarına yönelik algılarını incelemek için kullanılan ölçek, Moos ve Trickett (1987) tarafından geliştirilmiş, Doğan, Atılgan ve Demirci (2003) tarafından Türkçe'ye uyarlanmıştır. Ölçekte, 5 boyut (yakınlık, açık uçluluk, bütünleşme, kurallarda netlik ve fiziksel ortam) ve 35 madde bulunmaktadır. Tablo 2'de örnek maddelere yer verilmiştir. Ölçek, 5'li likert tipindedir (hiçbir zaman 1, nadiren 2, bazen 3, çoğu zaman 4, her zaman 5). Doğan vd. (2003) tarafindan yapilan araştırmada ölçeğin Cronbach Alpha güvenirlik katsayısı 0.85 , bu çalışmada 0.84 bulunmuştur.

Tablo 2. Genel Kimya Laboratuvar Sınıf Çevre Ölçeği Örnek Maddeler

\begin{tabular}{cl}
\hline Ölçek Boyutları & Örnek Maddeler \\
\hline Yakınlık & Sınıfımdaki öğrencilerle laboratuvarda iyi anlaşırım. \\
\hline Açık Uçluluk & Laboratuvar derslerinde ilgilendiğim kimyasal konularda araştırma yapma olanağım vardır. \\
\hline Bütünleşme & $\begin{array}{l}\text { Genel Kimya derslerimde yaptığım çalışmalar, laboratuvar etkinliklerim ile bir bütünlük } \\
\text { içerisindedir. }\end{array}$ \\
\hline Kurallarda Netlik & Laboratuvar derslerimde yaptığım etkinliklere kılavuzluk eden, net kurallar vardır. \\
\hline Fiziksel Ortam & Deneyleri yaparken laboratuvarı kalabalık bulurum. \\
\hline
\end{tabular}

\subsection{Verilerin Toplanması}

Kimya Laboratuvar Sınıf Çevre Ölçeği verileri Türkiye'de bulunan 10 farklı devlet üniversitesinde 2016-2017 eğitim öğretim yılının bahar döneminde öğrenim gören 557 Fen Bilgisi Öğretmenliği bölümü 1.sınıf öğretmen adaylarından toplanmıştır. Öğretmen adaylarının Genel Kimya Laboratuvarı sınıf çevresine yönelik algıları, güz döneminde almış oldukları Genel Kimya Laboratuvarı I dersiyle sınırlı kalmıştır.

\subsection{Verilerin Analizi}

"Fen Bilgisi öğretmen adaylarının Genel Kimya Laboratuvar çevresine yönelik algılarının yakınlık, açık uçluluk, bütünleşme, kurallarda netlik ve fiziksel ortam boyutları açısından 
durumu nedir?" şeklindeki birinci problem için, Kimya Laboratuvarı Sınıf Çevre Ölçeği' nden alınan en düşük ve en büyük puanların aralığı likert derecesine göre Tablo 3'teki gibi belirlenmiştir.

Tablo 3. Likert derecesine göre ölçekte alınan en düşük ve en büyük puan aralığ

\begin{tabular}{cccc}
\hline Likert Derecesi & Likert Tipi & En Düşük Puan & En Yüksek Puan \\
\hline $\mathbf{1}$ & Hiçbir Zaman & 7 & 12 \\
\hline $\mathbf{2}$ & Nadiren & 13 & 18 \\
\hline $\mathbf{3}$ & Bazen & 19 & 24 \\
\hline $\mathbf{4}$ & Çoğu Zaman & 25 & 30 \\
\hline $\mathbf{5}$ & Her Zaman & 31 & 36 \\
\hline
\end{tabular}

Tablo 3'te Kimya Laboratuvarı Sınıf Çevre Ölçeği' nden alınan en düşük ve en büyük puanların aralığı likert derecesine göre belirlenmiştir.

“Türkiye'de bulunan 10 farklı devlet üniversitesinde öğrenim gören Fen Bilgisi öğretmen adaylarının Genel Kimya Laboratuvar çevresine yönelik algılarında üniversiteler arasında yakınlık, açık uçluluk, bütünleşme, kurallarda netlik ve fiziksel ortam boyutları açısından farkl11ık var mıdır?" şeklindeki ikinci problem için, 10 farklı devlet üniversitesinde öğrenim gören Fen Bilgisi öğretmen adaylarının Genel Kimya Laboratuvar çevresine yönelik algılarında üniversiteler arasında yakınlık, açık uçluluk, bütünleşme, kurallarda netlik ve fiziksel ortam boyutları için grupların normal dağılımına D'Agostino-Pearson (DP) omnibus testiyle bakılmıştır.

Yakınlık boyutunda (Ü5, DP=23.04 $\mathrm{p}=0.000 ; \mathrm{U} 6, \mathrm{DP}=41.22 \mathrm{p}=0.000$; Ü8, $\mathrm{DP}=12.02$ $\mathrm{p}=0.002$; $\ddot{\mathrm{U}} 10, \mathrm{DP}=9.60 \mathrm{p}=0.008$ ), açı uçluluk boyutunda (Ü2, $\mathrm{DP}=41.84 \mathrm{p}=0.000$ ), bütünleşme boyutunda (Ü1, DP=20.28 p=0.000; Ü3, DP=31.96 p=0.000; Ü5, DP=9.72 $\mathrm{p}=0.007$; $\ddot{U} 6, \mathrm{DP}=20.90 \mathrm{p}=0.000$; $\ddot{\mathrm{U}} 9, \mathrm{DP}=12.94 \mathrm{p}=0.001$; $\ddot{\mathrm{U}} 10, \mathrm{DP}=8.36 \mathrm{p}=0.015$ ), kurallarda netlik boyutunda ( $\ddot{U} 1, D P=11.39 \mathrm{p}=0.000 ; \ddot{U} 3, \mathrm{DP}=34.01 \mathrm{p}=0.000$; Ü6, $\mathrm{DP}=30.53 \mathrm{p}=0.000 ; \ddot{\mathrm{U}} 7, \mathrm{DP}=8.91 \mathrm{p}=0.011 ; \ddot{\mathrm{U}} 9, \mathrm{DP}=12.71 \mathrm{p}=0.001 ; \ddot{U} 10, \mathrm{DP}=61.75$ $\mathrm{p}=0.000$ ), fiziksel ortam boyutunda (Ü9, $\mathrm{DP}=9.19 \mathrm{p}=0.001$ ) normal dağılımı sağlamayan gruplar olduğu için Kruskal Wallis testi uygulanmıştır.

Kruskal Wallis testi sonucuna göre; üniversitelerin ortalama sıralamalarına bakarak farklı1ığın olduğu tespit edilmiştir. Gruplar arasında ne kadar farklılığın olduğunu anlamak için Mann-Whitney U testi yapılmıştır. Bağımlı değişken üniversite, bağımsız değişkenler yakınlık, açık uçluluk, bütünleşme, kurallarda netlik ve fiziksel ortam boyutlarıdır. Anlamlılık düzeyi $\mathrm{p}=0.05 / 10=0.005$ olarak alınmıştır. Buna göre üniversiteler arasındaki farklılığa ikili gruplar halinde bakılmış ve üniversiteler arasındaki fark (Y-Z) hesaplanmıştır.

"Fen Bilgisi öğretmen adaylarının Genel Kimya Laboratuvar çevresine yönelik algılarında laboratuvar dersini veren öğretim elemanının Kimya ve Kimya/Fen Eğitimi uzmanlık alanına göre anlamlı farklılık var mıdır?" şeklindeki üçüncü problem için, Fen Bilgisi öğretmen adaylarının Genel Kimya Laboratuvar çevresine yönelik algılarında laboratuvar dersini veren öğretim elemanının uzmanlık alanına göre her boyut için grupların normal dağılımına 
D'Agostino-Pearson (DP) omnibüs testiyle bakılmıştır. Kimya uzmanlık alanı 1, Kimya/Fen Eğitimi uzmanlık alanı 2 olarak kodlanmıştır. Bağımlı değişken öğretim elemanının uzmanlık alanı, bağımsız değişkenler ise yakınlık, açı uçluluk, bütünleşme, kurallarda netlik ve fiziksel ortam boyutlarıdır. Verilerin normal dağılım göstermediği boyutlarda Mann Whitney U Testi (yakınlık, kurallarda netlik ve fiziksel ortam), normal dağılım gösterdiği boyutlarda (açık uçluluk ve bütünleşme) bağımsız örneklemde $t$ testi uygulanmıştır

\section{Bulgular}

Fen Bilgisi öğretmen adaylarının yakınlık, açık uçluluk, bütünleşme, kurallarda netlik ve fiziksel ortam boyutları açısından Genel Kimya Laboratuvar çevresine yönelik algıları Tablo 4 'te sunulmuştur.

Tablo 4. Boyutların likert tiplerine göre frekans ve yüzde değerleri

\begin{tabular}{|c|c|c|c|c|c|c|c|c|c|c|}
\hline \multirow[t]{2}{*}{ Likert Tipleri } & \multicolumn{2}{|c|}{ Yakınlık } & \multicolumn{2}{|c|}{ Açık Uçluluk } & \multicolumn{2}{|c|}{ Bütünleşme } & \multicolumn{2}{|c|}{$\begin{array}{c}\text { Kurallarda } \\
\text { Netlik }\end{array}$} & \multicolumn{2}{|c|}{ Fiziksel Ortam } \\
\hline & $\mathbf{f}$ & $\%$ & $\mathbf{f}$ & $\%$ & $\mathbf{f}$ & $\%$ & f & $\%$ & f & $\%$ \\
\hline Hiçbir Zaman & 1 & 0.18 & 5 & 0.90 & 1 & 0.19 & 0 & 0.00 & 6 & 1.08 \\
\hline Nadiren & 8 & 1.44 & 202 & 36.27 & 11 & 1.97 & 7 & 1.26 & 57 & 10.23 \\
\hline Bazen & 77 & 13.82 & 312 & 56.01 & 101 & 18.13 & 59 & 10.59 & 230 & 41.29 \\
\hline Çoğu Zaman & 355 & 63.73 & 38 & 6.82 & 281 & 50.45 & 289 & 51.88 & 237 & 42.55 \\
\hline Her Zaman & 116 & 20.83 & 0 & 0.00 & 163 & 29.26 & 202 & 36.27 & 27 & 4.85 \\
\hline Toplam & 557 & 100 & 557 & 100 & 557 & 100 & 557 & 100 & 557 & 100 \\
\hline
\end{tabular}

Fen Bilgisi Öğretmenliği adaylarının yakınlık boyutunda \% 63.73 ile en yüksek çoğu zaman daha sonra \% 20.83 ile her zaman, \%0.18 ile en düşük hiçbir zaman cevabı verilmiştir. Açık uçluluk boyutunda \% 56.01 ile en yüksek bazen, daha sonra \% 36.27 ile nadiren cevabı verilirken, her zaman cevabını veren öğretmen adayı olmamıştır. Bütünleşme boyutunda \% 50.45 ile en yüksek çoğu zaman, daha sonra \% 29.26 ile her zaman, $\% 0.19$ ile en düşük hiçbir zaman cevabını vermişlerdir. Kurallarda netlik boyutunda \% 51.88 ile en yüksek çoğu zaman, daha sonra \% 36.27 ile her zaman cevabı verilirken, hiçbir zaman cevabını veren öğretmen adayı olmamıştır. Fiziksel ortam boyutunda en yüksek değerlere sahip olan \% 42.55 ile çoğu zaman ve \%41.29 ile bazen, en düşük \%1.08 değerle hiçbir zaman cevab1 verilmiştir.

“Türkiye'de bulunan 10 farklı devlet üniversitesinde öğrenim gören Fen Bilgisi öğretmen adaylarının Genel Kimya Laboratuvar çevresine yönelik algılarında üniversiteler arasında yakınlık, açık uçluluk, bütünleşme, kurallarda netlik ve fiziksel ortam boyutları açısından farkl11ık var mıdır?" şeklinde belirtilen ikinci problem için, üniversitelere göre farklılığın olup olmadığına ilişkin bulgular; yakınlık boyutu (Tablo 5), açık uçluluk boyutu (Tablo 6), bütünleşme boyutu (Tablo 7), kurallarda netlik boyutu (Tablo 8) ve fiziksel ortam boyutu (Tablo 9) olarak sunulmuştur. 
Tablo 5. Yakınlık Boyutu Kruskal Wallis ve Mann-Whitney U Testi Sonuçları

\begin{tabular}{|c|c|c|c|c|c|c|c|c|}
\hline \multirow[t]{2}{*}{ Alt boyut } & \multicolumn{5}{|c|}{ Kruskal Wallis } & \multicolumn{3}{|c|}{$\begin{array}{c}\text { Mann } \\
\text { Whitney U }\end{array}$} \\
\hline & Üniversite & $\mathbf{N}$ & Ort & $\mathrm{X}^{2}$ & Sd & $P<0.05$ & $P<0.005$ & $\mathbf{Y}-\mathbf{Z}$ \\
\hline \multirow{10}{*}{ Yakınlık } & $\ddot{\mathrm{U} 1}$ & 48 & 261.75 & \multirow{10}{*}{43.515} & \multirow{10}{*}{9} & \multirow{10}{*}{$0.000 *$} & Ü3-Ü4 & 121.68 \\
\hline & Ü2 & 33 & 244.70 & & & & Ü4-Ü5 & -100.72 \\
\hline & Ü3 & 49 & 305.26 & & & & \multirow[t]{2}{*}{ Ü4-Ü6 } & \multirow[t]{2}{*}{-142.1} \\
\hline & $\ddot{\mathrm{U}} 4$ & 59 & 183.58 & & & & & \\
\hline & Ü5 & 64 & 284.30 & & & & \multirow[t]{2}{*}{ Ü4-Ü8 } & \multirow[t]{2}{*}{-156.32} \\
\hline & Ü6 & 86 & 325.68 & & & & & \\
\hline & Ü7 & 76 & 248.38 & & & & \multirow[t]{2}{*}{ Ü4-Ü10 } & \multirow[t]{2}{*}{-139.22} \\
\hline & Ü8 & 24 & 339.90 & & & & & \\
\hline & Ü9 & 44 & 269.31 & & & & \multirow[t]{2}{*}{ Ü6-Ü7 } & \multirow[t]{2}{*}{77.3} \\
\hline & Ü10 & 74 & 322.80 & & & & & \\
\hline
\end{tabular}

\section{$* \mathbf{P}<0.05$}

Yakınlık boyutu Kruskal Wallis testi sonucuna göre; üniversitelerin ortalama sıralamaları (Ü1 $=261.75 ; \quad \ddot{U} 2=244.70 ; \ddot{U} 3=305.26 ; \quad \ddot{U} 4=183.58 ; \quad \ddot{U} 5=284.30 ; \ddot{U} 6=325.68 ; \quad \ddot{U} 7=248.38$; Ü8=339.90; Ü9=269.31; Ü10=322.80) farkl111k göstermektedir $\left(X^{2}=43.515 \mathrm{sd}=9 \mathrm{p}=0.000\right)$. Gruplar arasında ne kadar farklılığın olduğunu anlamak için Mann-Whitney U testi yapılmıştır. Anlamlılık düzeyi ise $\mathrm{p}=0.05 / 10=0.005$ olarak alınır. Buna göre Ü3-Ü4, Ü4-Ü5, Ü4-Ü6, Ü4-Ü8, Ü4-Ü10 ve Ü6-Ü7 arasinda (p<0.005) farkl11ık vardır. 
Tablo 6. Açık Uçluluk Boyutu Kruskal Wallis ve Mann-Whitney U Testi Sonuçları

\begin{tabular}{|c|c|c|c|c|c|c|c|c|}
\hline \multirow[t]{2}{*}{ Alt boyut } & \multicolumn{5}{|c|}{ Kruskal Wallis } & \multicolumn{3}{|c|}{$\begin{array}{c}\text { Mann- } \\
\text { Whitney U }\end{array}$} \\
\hline & Üniversite & $\mathbf{N}$ & Ort & $\mathbf{X}^{2}$ & Sd & $\mathbf{P}<0.05$ & $P<0.005$ & $\mathbf{Y}-\mathbf{Z}$ \\
\hline \multirow{16}{*}{$\begin{array}{c}\text { Açık } \\
\text { Uçluluk }\end{array}$} & & & & \multirow{16}{*}{82.521} & \multirow{16}{*}{9} & \multirow{16}{*}{$0.000 *$} & Ü1-Ü3 & 112.86 \\
\hline & U1 & 48 & 273.82 & & & & Ü1-Ü4 & -135.51 \\
\hline & & & & & & & Ü2-Ü3 & 152.01 \\
\hline & Ü2 & 33 & 312.97 & & & & Ü2-Ü4 & -96.36 \\
\hline & \multirow{2}{*}{ Ü3 } & \multirow{2}{*}{49} & \multirow{2}{*}{160.96} & & & & Ü3-Ü4 & -248.37 \\
\hline & & & & & & & Ü3-Ü6 & -154.79 \\
\hline & \multirow{2}{*}{ Ü4 } & \multirow[b]{2}{*}{59} & \multirow[b]{2}{*}{409.33} & & & & Ü3-Ü7 & -110.57 \\
\hline & & & & & & & Ü3-Ü9 & -135.59 \\
\hline & \multirow[b]{2}{*}{ Ü5 } & \multirow[b]{2}{*}{64} & \multirow[b]{2}{*}{230.97} & & & & Ü3-Ü10 & -94.26 \\
\hline & & & & & & & Ü4-Ü5 & 178.36 \\
\hline & \multirow[b]{2}{*}{ Ü6 } & \multirow[b]{2}{*}{86} & \multirow[b]{2}{*}{315.75} & & & & Ü4-Ü6 & 93.58 \\
\hline & & & & & & & Ü4-Ü7 & 137.80 \\
\hline & $\ddot{\text { Ü7 }}$ & 76 & 271.53 & & & & Ü4-Ü8 & 184.87 \\
\hline & Ü8 & 24 & 224.46 & & & & Ü4-Ü9 & 112.78 \\
\hline & Ü9 & 44 & 296.55 & & & & Ü4-Ü10 & 154.11 \\
\hline & Ü10 & 74 & 255.22 & & & & Ü5-Ü6 & -84.78 \\
\hline
\end{tabular}

$* \mathbf{P}<\mathbf{0 . 0 5}$

Açık uçluluk boyutu Kruskal Wallis testi sonucuna göre; üniversitelerin ortalama siralamalar1 (Ü1 $=273.82 ; \quad \ddot{U} 2=312.97 ; \quad \ddot{U} 3=160.96 ; \quad \ddot{U} 4=409.33 ; \quad \ddot{U} 5=230.97 ; \quad \ddot{U} 6=315.75$; $\ddot{U} 7=271.53 ; \quad \ddot{U} 8=224.46 ; \quad \ddot{U} 9=296.55 ; \quad \ddot{U} 10=255.22)$ farkl111k göstermektedir $\left(X^{2}=82.521\right.$ $\mathrm{sd}=9 \mathrm{p}=0.000$ ). Gruplar arasında ne kadar farklılığın olduğunu anlamak için Mann-Whitney $\mathrm{U}$ testi yapılmıştır. Anlamlılık düzeyi ise $\mathrm{p}=0.05 / 10=0.005$ olarak alınır. Buna göre Ü1-Ü3, Ü1-Ü4, Ü2-Ü3, Ü2-Ü4, , Ü3-Ü4, Ü3-Ü6, Ü3-Ü7, Ü3-Ü9, Ü3-Ü10, Ü4-Ü5, Ü4-Ü6, Ü4-Ü7, Ü4-Ü8, Ü4-Ü9, Ü4-Ü10 ve Ü5-Ü6 (p<0.005) arasinda farkl111klar vardır. 
Tablo 7. Bütünleşme Boyutu Kruskal Wallis ve Mann-Whitney U Testi Sonuçları

\begin{tabular}{|c|c|c|c|c|c|c|c|c|}
\hline \multirow[t]{2}{*}{ Alt boyut } & \multicolumn{5}{|c|}{ Kruskal Wallis } & \multicolumn{3}{|c|}{$\begin{array}{c}\text { Mann- } \\
\text { Whitney U }\end{array}$} \\
\hline & Üniversite & $\mathbf{N}$ & Ort & $\mathbf{X}^{2}$ & Sd & $\mathbf{P}<\mathbf{0 . 0 5}$ & $P<0.005$ & Y-Z \\
\hline \multirow{16}{*}{ Bütünleşme } & & & & \multirow{16}{*}{88.829} & \multirow{8}{*}{9} & \multirow{8}{*}{$0.000 *$} & Ü1-Ü3 & -85.05 \\
\hline & Ü1 & 48 & 304.02 & & & & Ü1-Ü4 & 137.27 \\
\hline & & & & & & & Ü1-Ü7 & 100.63 \\
\hline & Ü2 & 33 & 238.61 & & & & Ü2-Ü3 & -150.46 \\
\hline & \multirow[b]{2}{*}{ Ü3 } & \multirow[b]{2}{*}{49} & \multirow[b]{2}{*}{389.07} & & & & Ü3-Ü4 & 222.32 \\
\hline & & & & & & & Ü3-Ü6 & 112.45 \\
\hline & \multirow[b]{2}{*}{ Ü4 } & \multirow[b]{2}{*}{59} & \multirow[b]{2}{*}{166.75} & & & & Ü3-Ü7 & 185.68 \\
\hline & & & & & & & Ü3-Ü8 & 149.59 \\
\hline & \multirow[b]{2}{*}{ Ü5 } & \multirow[b]{2}{*}{64} & \multirow[b]{2}{*}{332.34} & & & & Ü4-Ü5 & -165.59 \\
\hline & & & & & & & Ü4-Ü6 & -109.87 \\
\hline & \multirow[b]{2}{*}{ Ü6 } & \multirow[b]{2}{*}{86} & \multirow[b]{2}{*}{276.62} & & & & Ü4-ய̈9 & -140.82 \\
\hline & & & & & & & Ü4-Ü10 & -160.76 \\
\hline & Ü7 & 76 & 203.39 & & & & Ü5-ய̈7 & 128.95 \\
\hline & Ü8 & 24 & 239.48 & & & & Ü6-Ü7 & 73.23 \\
\hline & Ü9 & 44 & 307.57 & & & & Ü7-Ü9 & -104.18 \\
\hline & Ü10 & 74 & 327.51 & & & & Ü7-Ü10 & -124.12 \\
\hline
\end{tabular}

Bütünleşme boyutu Kruskal Wallis testi sonucuna göre; üniversitelerin ortalama sıralamaları (Ü1=304.02; $\ddot{\mathrm{U}} 2=238.61 ; \quad \ddot{U} 3=389.07 ; \quad \ddot{U} 4=166.75 ; \quad \ddot{U} 5=332.34 ; \quad \ddot{U} 6=276.62 ; \quad \ddot{U} 7=203.39$; $\ddot{\mathrm{U}} 8=239.48$; $\ddot{\mathrm{U}} 9=307.57$; $\ddot{\mathrm{U}} 10=327.51)$ farkl11.k göstermektedir $\left(\mathrm{X}^{2}=88.829 \mathrm{sd}=9 \mathrm{p}=0.000\right)$. Gruplar arasında ne kadar farklılığın olduğunu anlamak için Mann-Whitney U testi yapılmıştır. Anlamlılık düzeyi ise $\mathrm{p}=0.05 / 10=0.005$ olarak alınır. Buna göre Ü1-Ü3, Ü1-Ü4,

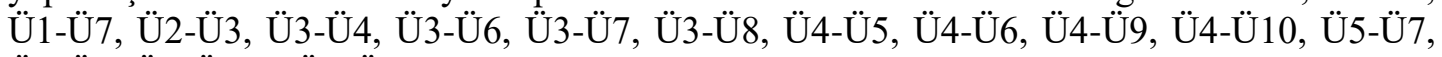
Ü6-Ü7, Ü7-Ü9 ve Ü7-Ü10 arasında (p<0.005) farklılıklar vardır. 
Tablo 8. Kurallarda Netlik Boyutu Kruskal Wallis ve Mann-Whitney U Testi Sonuçları

\begin{tabular}{|c|c|c|c|c|c|c|c|c|}
\hline \multirow[t]{2}{*}{ Alt boyut } & \multicolumn{6}{|c|}{ Kruskal Wallis } & \multicolumn{2}{|c|}{ Mann-Whitney U } \\
\hline & Üniversite & $\mathbf{N}$ & Ort & $\mathbf{X}^{2}$ & Sd & $P<0.05$ & $P<0.005$ & $\mathbf{Y}-\mathbf{Z}$ \\
\hline & Ü1 & 48 & 367.28 & & & & Ü1-Ü2 & 165.36 \\
\hline & & & & & & & Ü1-Ü4 & 232.75 \\
\hline & Ü2 & 33 & 201.92 & & & & Ü1-Ü5 & 92.17 \\
\hline & & & & & & & Ü1-Ü6 & 86.05 \\
\hline & & & & & & & Ü1-Ü7 & 161.17 \\
\hline & Ü3 & 49 & 367.09 & 123.628 & 9 & $0.000 *$ & Ü2-Ü3 & -165.17 \\
\hline & & & & & & & Ü2-Ü8 & -125.62 \\
\hline & $\ddot{\mathrm{U} 4}$ & 59 & 134.53 & & & & Ü2-Ü10 & -160.51 \\
\hline & & & & & & & Ü3-Ü4 & 232.56 \\
\hline \multirow{13}{*}{$\begin{array}{c}\text { Kurallarda } \\
\text { Netlik }\end{array}$} & & & & & & & Ü3-Ü5 & 91.98 \\
\hline & Ü5 & 64 & 275.11 & & & & Ü3-Ü6 & 85.86 \\
\hline & & & & & & & Ü3-Ü7 & 160.98 \\
\hline & Ü6 & 86 & 281.23 & & & & Ü4-Ü5 & -140.58 \\
\hline & & & & & & & Ü4-ய̈6 & -146.70 \\
\hline & & & & & & & Ü4-Ü7 & -71.58 \\
\hline & Ü7 & 76 & 206.11 & & & & Ü4-Ü8 & -193.01 \\
\hline & & & & & & & Ü4-Ü9 & -162.00 \\
\hline & Ü8 & 24 & 327.54 & & & & Ü4-10 & -227.90 \\
\hline & & & & & & & Ü5-Ü7 & 69 \\
\hline & & & & & & & Ü5-Ü10 & -87.32 \\
\hline & Ü9 & 44 & 296.53 & & & & Ü6-Ü7 & 75.12 \\
\hline & & & & & & & Ü6-Ü10 & -81.2 \\
\hline
\end{tabular}




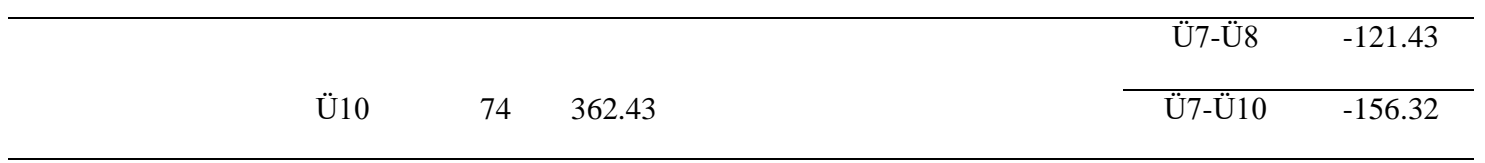

$* \mathbf{P}<\mathbf{0 . 0 5}$

Kurallarda netlik boyutu Kruskal Wallis testi sonucuna göre; üniversitelerin ortalama siralamalar1 (Ü1 $=367.28$, Ü2 $=201.92$, Ü3 $=367.09$, Ü4 $=134.53$, Ü5 $=275.11, \ddot{U} 6=281.23$, $\ddot{\mathrm{U}} 7=206.11, \ddot{\mathrm{U}} 8=327.54, \ddot{\mathrm{U}} 9=296.53$, Ü10 $=362.43)$ farkl111k göstermektedir $\left(X^{2}=123.628\right.$ $\mathrm{sd}=9 \mathrm{p}=.000$ ). Gruplar arasında ne kadar farklılı̆̆ın olduğunu anlamak için Mann-Whitney $\mathrm{U}$ testi yapılmıştır. Anlamlılık düzeyi ise $\mathrm{p}=0.05 / 10=0.005$ olarak alınır. Buna göre Ü1-Ü2, Ü1-Ü4, Ü1-Ü5, Ü1-Ü6, Ü1-Ü7, Ü2-Ü3, Ü2-Ü8, Ü2-Ü10, Ü3-Ü4, Ü3-Ü5, Ü3-Ü6, Ü3-Ü7, Ü4-Ü5, Ü4-Ü6, Ü4-Ü7, Ü4-Ü8, Ü4-Ü9, ய̈4-Ü10, Ü5-Ü7, Ü5-Ü10, Ü6-Ü7, Ü6-Ü10, Ü7- Ü8 ve Ü7-Ü10 arasında $(\mathrm{p}<0.005)$ farklılıklar vardır.

Tablo 9. Fiziksel Ortam Boyutu Kruskal Wallis ve Mann-Whitney U Testi Sonuçları

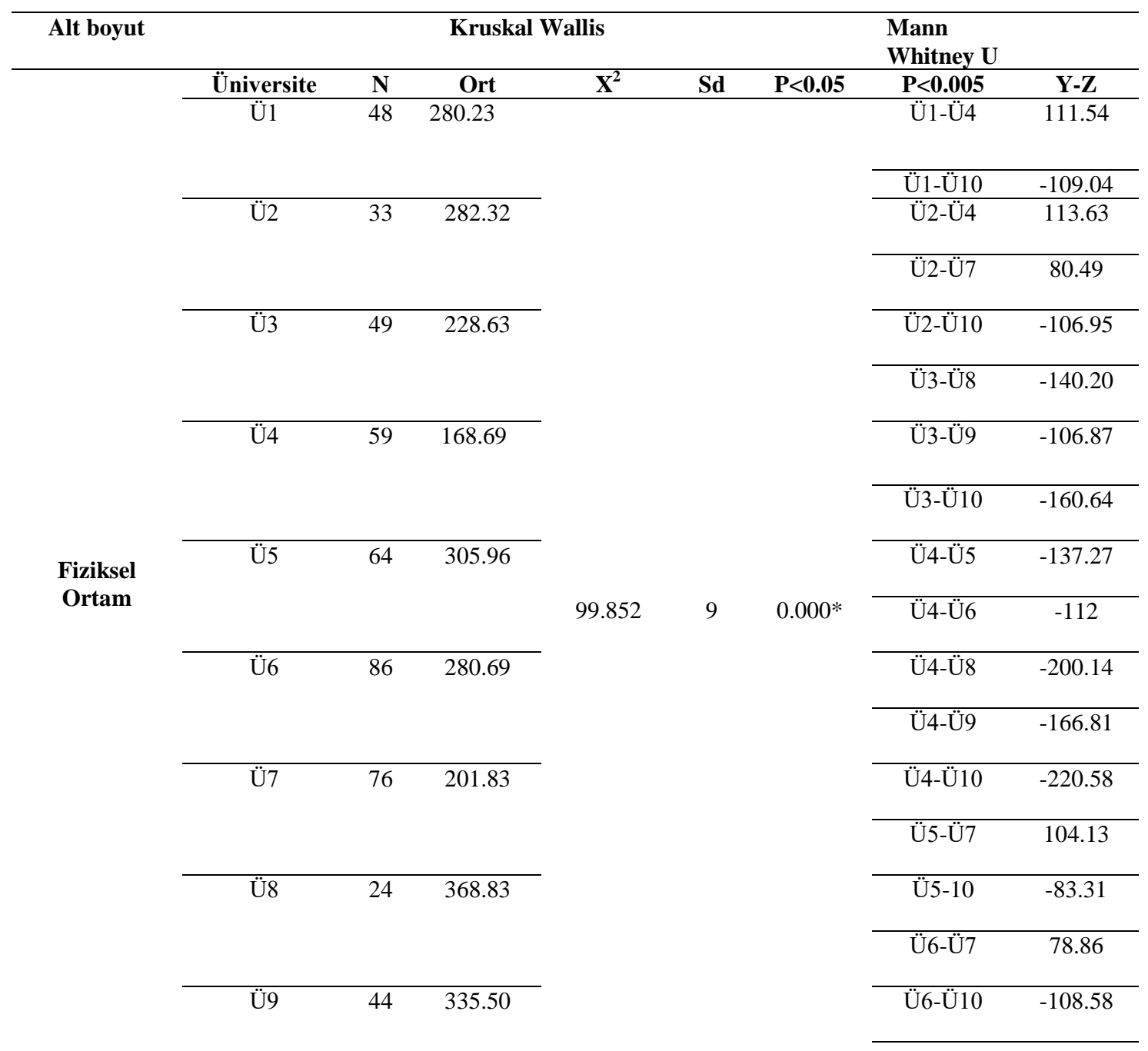




\begin{tabular}{lll} 
& & \\
\hline Ü10 & 74 & 389.27
\end{tabular}

\begin{tabular}{cc}
\hline Ü7-Ü8 & -167 \\
\hline Ü7-Ü9 & -133.67 \\
\hline Ü7-Ü10 & -187.44
\end{tabular}

$* \mathrm{P}<0.05$

Fiziksel ortam boyutu Kruskal Wallis testi sonucuna göre; üniversitelerin ortalama

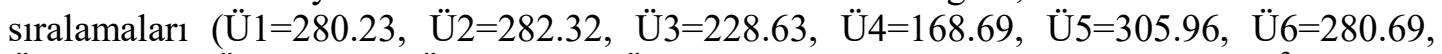
$\ddot{\mathrm{U}} 7=201.83$, Ü8 $8=368.83$, Ü9=335.50, Ü10=389.27 $)$ farkl11ı göstermektedir $\left(X^{2}=99.852\right.$ $\mathrm{sd}=9 \mathrm{p}=0.000$ ). Gruplar arasında ne kadar farklılı̆̆ın olduğunu anlamak için Mann-Whitney $\mathrm{U}$ testi yapılmıştır. Anlamlılık düzeyi ise $\mathrm{p}=0.05 / 10=0.005$ olarak alınır. Buna göre Ü1-Ü4, Ü1-Ü10, ய̈2-Ü4, Ü2-Ü7, Ü2-Ü10, Ü33-Ü8, Ü3-Ü9, Ü3-Ü10, Ü4-Ü5, Ü4-Ü6, Ü4-Ü8, Ü4-Ü9, Ü4-Ü10, ய̈5-Ü7, Ü5-10, ய̈6-Ü7, ய̈6-Ü10, ய̈7-Ü8, Ü7-ய̈9 ve Ü7-Ü10 arasinda $(\mathrm{p}<0.005)$ farklilıklar vardir.

“Fen Bilgisi öğretmen adaylarının Genel Kimya Laboratuvar çevresine yönelik algılarında laboratuvar dersini veren öğretim elemanının Kimya ve Kimya/Fen Eğitimi uzmanlık alanına göre anlamlı farklılık var mıdır?" şeklinde belirtilen üçüncü problem; yakınlık, kurallarda netlik ve fiziksel ortam boyutlarında normal dağılım göstermediği için Mann-Whitney $U$ testi kullanılmıştır. Bu problemine ait bulgular Tablo 10'da sunulmuştur. Açık uçluluk ve bütünleşme boyutları normal dağılım gösterdiği için bağımsız örneklemde $t$ testi kullanılmıştır. Bu testin sonuçları Tablo 11' de verilmiştir.

Tablo 10. Yakınlık, Kurallarda Netlik ve Fiziksel Ortam Boyutu Mann-Whitney U Testi Sonuçları

\begin{tabular}{ccccc}
\hline Alt Boyut & $\begin{array}{c}\text { Öğretim Görevlisinin } \\
\text { Uzmanlık Alanı }\end{array}$ & $\begin{array}{c}\text { N (Öğretmen } \\
\text { Adayı Sayısı) }\end{array}$ & $\begin{array}{c}\text { Ortalama } \\
\text { Sıralama }\end{array}$ & P<0.05 \\
\hline \multirow{2}{*}{ Yakınlık } & Kimya (n=5) & 296 & 283.76 & \\
\hline Kurallarda & Kimya/Fen Eğitimi (n=5) & 261 & 273.60 & 0.456 \\
Netlik & Kimya (n=5) & 296 & 286.29 & \multirow{2}{*}{0.253} \\
\hline Fiziksel Ortam & Kimya/Fen Eğitimi (n=5) & 261 & 270.73 & \multirow{2}{*}{0.248} \\
& Kimya/Fen Eğitimi (n=5) & 261 & 286.29 & \\
\hline
\end{tabular}

Tablo 10’ da, öğretim elemanının Kimya ve Kimya/Fen Eğitimi uzmanlık alanına göre yakınlık, kurallarda netlik ve fiziksel ortam boyutlarında fark istatistiksel olarak anlamlı bulunmamıştır (Yakınlık p>0.05; Kurallarda Netlik p>0.05; Fiziksel Ortam p>0.05). 


\begin{tabular}{|c|c|c|c|c|c|c|c|}
\hline Boyut & $\begin{array}{c}\text { Öğretim } \\
\text { Görevlisinin } \\
\text { Uzmanlık Alanı }\end{array}$ & $\begin{array}{l}\text { N (Öğretmen } \\
\text { Adayı Sayısı) }\end{array}$ & Ort & Ss & $\mathbf{t}$ & Df & $\mathbf{P}^{*}$ \\
\hline \multirow[t]{2}{*}{ Açık Uçluluk } & Eğitim $(n=5)$ & 261 & 20.46 & 3.21 & & & \\
\hline & Kimya $(n=5)$ & 296 & 18.98 & 3.13 & 5.477 & 555 & 0.000 \\
\hline \multirow[t]{2}{*}{ Bütünleşme } & Eğitim $(n=5)$ & 261 & 28.52 & 5.08 & & & \\
\hline & Kimya $(n=5)$ & 296 & 29.70 & 4.60 & -2.871 & 555 & 0.004 \\
\hline
\end{tabular}

Tablo 11' de, öğretim elemanının Kimya ve Kimya/Fen Eğitimi uzmanlık alanında açık uçluluk $(\mathrm{p}<0.05)$ ve bütünleşme $(\mathrm{p}<0.05)$ boyutlarında farklılık görülmektedir. Açık uçluluk boyutunda eğitim lehine, bütünleşme boyutunda kimya lehine anlamlı farklılık bulunmuştur.

\section{Sonuç ve Tartışma}

Öğretmen adaylarının laboratuvar çevresine yönelik algılarında üniversite öncesinde ve üniversitede geçirdikleri öğretim yaşantılarının önemli etkisi bulunmaktadır. Algılarında öğrenme ve öğretimle ilgili inançlarla ilişkili olduğu düşünülürse bu durumda Genel Kimya Laboratuvarındaki deneyimlerinin öğretmenlik yaşantılarında fen derslerinde kullanacakları yöntem ve tekniklerin üzerinde belirleyici etkisi olacağı söylenebilir. Bu çalışmada Fen Bilgisi öğretmen adaylarının Genel Kimya Laboratuvar çevresine yönelik algılarını yakınlık, açık uçluluk, bütünleşme, kurallarda netlik ve fiziksel ortam boyutları açısından incelenmiştir. Bunun için 10 farklı üniversitede yer alan Fen bilgisi öğretmen adaylarıyla çalışılmıştır. $\mathrm{Bu}$ adayların Genel Kimya Laboratuvar çevresine yönelik algılarında laboratuvar dersini veren öğretim elemanının Kimya ve Kimya/Fen Eğitimi uzmanlık alanına göre anlamlı farklılığın olup olmadığı araştırılmıştır.

Moos ve Trickett (1987)'ın geliştirdiği yakınlık boyutu, öğrencilerin birbirlerini tanıması, birbirlerine yardım etmesi ve birbirlerini desteklemesi derecesidir. Eğer laboratuvar ortamları iyi tasarlanırsa öğrenciler öğretmenleri ve akranlarıyla yakından etkileşime girer, böylece öğrenme etkili bir şekilde izlenebilir, değerlendirilebilir ve geliştirilebilir (Boud, Dunn ve Hegarty-Hazel, 1986; Hegarty-Hazel 1990). Bu durumda sınıfta etkili bir öğrenme çevresi yaratılmasının, öğrencilerin bilişsel ve duyuşsal öğrenme ürünleri üzerinde olumlu bir etkide bulunabileceği ileri sürülebilir (Doğan, Atılgan ve Demirci, 2003). Haertel, Walberg ve Haertel (1981)'in çalışmasında çeşitli ülkelerde sınıf çevresine ilişkin öğrenci algılarında bilişsel ve duyuşsal ürünler arasında ilişkiler saptanmıştır. Maurer (1985)'in grup gelişimi olarak tanımladığı 4 aşama (grup oluşturma, fırtına/tepki, normlar/kural tanımları ve uygulama) Moos ve Trickett (1987)'in geliştirdiği boyutlar ile ilişkilendirilebilir. İlk aşama öğrencilerin kaynaşması ve grup üyeliği ile ilgili ilişkileri içermektedir. Öğrenciler 
sorumluluklarını kabul etmeye ilişkin sorunlarını çözmektedir. 2. aşamada öğrenciler sorumluluklarının sınırlarını sınamaya başlamaktadır. Bu sınama esnasında, öğrenciler kuralların hangi şartlarda uygulanıp uygulanmayacağını anlamak üzere öğretmene karşı çıkabilirler. Oturma düzenini, ödevleri ve sınıf içi çalışmaları sorgulayabilirler. 3. aşamada öğrenciler kuralları, prosedürleri ve normları kabul eder. Son aşamada öğrencilerin öğretmenden bağımsız bir şekilde sorumluluklarını bilerek çalıştıkları aşamadır. Fraser, Giddings ve McRobbie (1992)'in geliştirdiği 5 boyut (öğrenci ilişkileri, deneylerin doğası, ders-laboratuvar ilişkisi, laboratuvar kuralları ve laboratuvar malzemeleri), Moos ve Trickett (1987)'ın geliştirdiği 5 boyut (yakınlık, açık uçluluk, bütünleşme, kurallarda netlik ve fiziksel ortam) ile ilişkilendirilebilir. Bu çalışmanın yakınlık boyutunda, öğretmen adaylarının laboratuvar ortamlarında birbirlerini tanıdığı, birbirlerine yardım ettiği, arkadaşları ile etkileşim halinde olduğu, iyi anlaştıkları ve iş birliği yaptıklarını gösteren Genel Kimya Laboratuvar çevresine yönelik algıları "çoğu zaman" ve "her zaman" düzeyindedir. Öğretmen adaylarının yakınlık boyutundaki algıları Maurer (1985)'in geliştirdiği grup oluşturma aşaması ile ve Fraser vd. (1992)'nin geliştirdiği öğrenci ilişkileri ile uyum gösterdiği söylenebilir. Şenler, Karışan ve Bilican (2017)'ın yapmış olduğu çalışmada da öğrencilerin birbirleri ile iyi geçindiği, gerektiğinde birbirlerine yardım ettikleri, birbirleri ile iyi iletişim kurabildikleri bir atmosferde deney ve etkinlik yaptıkları belirlenmiştir. Landsman ve Lewis (2011), öğrencilerin birbirine güvenmeleri ve kendilerini sınıfın bir üyesi olarak hissetmelerini sağlayacak etkinliklerin olması gerektiğinden bahsetmektedir. Öğrenciler öğrenme gruplarında birbirlerinin öğrenmesinin sorumluluğunu üsteleneceği için işbirlikli öğrenme ortamı oluşturulmuş olacaktır (Sucuoğlu, 2017, s.357). İşbirlikli öğrenme, öğrencileri öğretme sürecine aktif olarak dahil eder ve onların eleştirel düşünme, akıl yürütme ve problem çözme becerilerini iyileştirmeye çalışır (Jacobs, Power ve Loh, 2002). Öğrenci bilgiyi anlayacak, özümseyecek, kullanacak ve üretecektir. Bunları yaparken bildiklerini, becerilerini, duygularını etkin bir şekilde kullanmalı, diğer öğrencilerle iş birliği yapmalıdır (Sönmez, 2012 s.377). İş birliği yapan öğrenciler grup çalışmasıyla hem kendilerinin hem de arkadaşlarının kapasitelerini geliştirmeye çalışılar. Bu, tek tek her öğrencinin öğretilenleri öğrenmesinden farklıdır. Grup çalışması sırasında öğrenciler tek başlarına değil, başkalarıyla etkileşim halinde olacaklardır (Açıkgöz, 2000, s.259).

Açık uçluluk boyutu, her öğrencinin aynı deneyleri yapmaya zorlanmaması, her öğrenciye istediğinde farklı deney yapabilme şansını tanıma derecesidir. Bu çalışmada, laboratuvarda öğrencilere tanınan çalışma konusu esnekliği; yani her öğrencinin aynı deneyi yapmaya zorlanmaması, her öğrenciye istediğinde farklı deney yapabilme şansının tanınma derecesi "nadiren" ve "bazen" düzeyindedir. Bu durum Genel Kimya laboratuvarlarında sorgulama düzeyinin gerçekleştiği ortamlarda açık uçluluk boyutunun iyileştirilmesi gerektiğini, öğrencilerin ilgilendiği deneylerde, kimyasal konularda araştırma yapma olanağını bulması, deneyleri öğrencilerin tasarlaması, öğrencilerin farklı deney yapmak istediğinde öğretim görevlilerinin izin vermesi, bu konuda öğrenciyi desteklemesi gerektiğini göstermektedir. Öğretmen adaylarının deney sürecinde izlenmesi gereken yollara kendilerinin karar vermesi Fraser vd. (1992)'nin geliş̧irdiği deneylerin doğası aşaması ile ilişkilidir. Öğrenciler laboratuvar derslerinde, ilgilendiği konularda araştırma yapma olană̆ına sahip olursa, verilen bir konuda arkadaşlarından farklı deneyler tasarlarsa, laboratuvar saatleri dışında da laboratuvarı kullanmasına izin verilirse, deney yaparken izlenecek yola öğretmen değil öğrenci karar verirse, öğrencilerin laboratuvara yönelik algıları olumlu yönde artar (Duru, Demir, Önen ve Benzer, 2011). Deneyler hazırlanırken öğrencilere kendi deneylerini tasarlayabilecekleri imkanlar sağlanmalı, öğrenciler deney sürecinde izlenmesi gereken yollara kendileri karar vermeli, öğretmenin rehber konumunda olduğu açik uçlu ya da hipotezi test etme deneylerine daha çok yer verilmelidir (Şenler, Karışan ve Bilican, 2017). 
Ames (1990), Maehr ve Midgley (1991) ve Anderman ve Maehr (1994)' e göre programların esnek olduğu, öğrencilerin yönetimde sorumluluk aldığı ortamlar öğrenciyi etkin kılacaktır. Etkin öğrenmede (deneysel öğrenme), öğrenci yaparak ve yaşayarak, tüm duyu organlarını kullanarak öğrenir. Öğrenci dinlemeden çok etkinliğe etkin katılır, tartışır, öneri sunar, bilginin aktarılmasından çok becerilerin gelişmesini sağlar. Analiz, sentez, değerlendirme basamaklarındaki hedef davranışları kazanabilir (Sönmez, 2012 s.377). Feyzioğlu vd., (2011), İzmir ilinde görev yapan kimya öğretmenlerinin genellikle kapalı uçlu deneyler yaptıklarını belirlemişlerdir. Öğretmenler ya deneyi kendileri yapmaktalar ya da öğrencilere deneyin nasıl yapılacağını adım adım vererek düzenli yürümesini denetlemektedir. Ancak öğrencinin istediği zaman laboratuvardan yararlanabildiği, laboratuvar saatlerinin sinırlı olmadığı ve aynı deneyi yapmaya zorlanmadıkları durumda akademik başarı, sorgulama becerisi, yaratıcılık, paylaşım ve iletişim becerilerinin arttığı Ergin, Yıldız ve Akpınar (2005) ile Hofstein, Shore ve Kipnis (2004) yapmış oldukları çalışmada belirlenmiştir.

Bütünleşme boyutu, laboratuvardaki etkinliklerin teorik derslerdeki konularla bütünleşme derecesidir. $\mathrm{Bu}$ çalışmanın laboratuvardaki etkinliklerin teorik derslerdeki konularla bütünleşme derecesi "çoğu zaman" ve "her zaman" düzeyindedir. Bu sonuç, laboratuvar etkinliklerinin Genel Kimya dersinde işlenen konularla ilişkili olduğunu göstermektedir. Bütünleşme boyutu Fraser vd. (1992)'nin geliştirdiği ders-laboratuvar ilişkisi aşaması ile uyumlu olduğu söylenebilir. Aydoğdu (1999), laboratuvar uygulamalarında teorik bilgi eksikliği çektiklerini belirtmiştir. $\mathrm{Bu}$ eksikliğin teorik derslerle laboratuvar uygulaması içeriklerinin farklı olmasından kaynaklandığı görüşündedir. Ayas, Özmen, Karamustafaoğlu ve Sevim'in (2002) yapmış olduğu çalışmada, öğrenciler teorik derslerde gördüğü bilgilerle laboratuvarda yaptığı uygulamaların paralel gitmediğini, Büyükekşi ve Yavuz (2015)'un araştırmasında teorik Kimya bilgilerini pratiğe dökememenin problem yarattığını tespit etmiştir. Kimya dersinin etkili bir şekilde anlaşılması için deneyler ile desteklenmesi gerekmektedir (Aydoğdu, 2017). Laboratuvarların derslerde verilen teorik bilgilerin uygulandığı bir ortam olduğu düşünüldüğünde, Genel Kimya dersi ile Genel Kimya laboratuvarı uygulamaları arasında ilişkinin sağlanması öğretmen adaylarının laboratuvara yönelik algılarını olumlu yönde etkileyeceği söylenebilir.

Kurallarda netlik boyutu, laboratuvarda çalışma kurallarının açıklığı ve formal olarak belirlenme derecesidir. Bu çalışmada laboratuvarda çalışma kurallarının açıklığı ve formal olarak belirlenme derecesi "çoğu zaman" ve "her zaman" düzeyindedir. Bu boyutta yer alan ölçek maddelerine göre, laboratuvarda yapılan etkinliklere kılavuzluk eden kuralların olduğu, derslerin çoğu zaman denetimsiz geçmediği, çalışmalar sırasında uyması gereken kuralların olduğu, diğer derslere göre daha belirgin kurallarla yürütüldüğü, deneye başlamadan önce öğretmenin deney için alınması gereken güvenlik önlemlerini açıkladığı söylenebilir. Aydoğdu (1999) tarafindan yapılan araştırmada, laboratuvarda görevlilerin yeterince rehberlik yapmadıklarını, öğretim görevlisinden yardım istemede güçlük yaşadıklarını, laboratuvar kılavuzundaki kuralların net olmamasından ne yapacaklarını anlayamadıklarını, bu yüzden de kendilerini deneyleri hazırlamada yetersiz hissettiklerini belirtmiş̧lerdir. Kurallarda netlik boyutu, Maurer (1985)'in grup gelişimi olarak tanımladığ 3. aşaması "Normlar/Kural Tanımları" ile ve Fraser vd. (1992)'nin geliştirdiği laboratuvar kuralları aşaması ile uyumlu olduğu söylenebilir. Öğrencilerin laboratuvar uygulamalarıyla ilgili beklentileri, iş birliği yaptığı grup üyelerinin nasıl düşünmeleri, hissetmeleri ve davranmaları gerektiğine ilişkin paylaştıkları beklentiler normları temsil etmektedir. Sosyal psikologlar, normları grup davranışlarının temel düzenleyicisi olarak görmektedir (Di Giullio, 2006). Sinıfta meydana gelebilecek disiplin problemlerini önlemek için kural ve prosedürler en etkili yöntemlerdir (Emmer ve Evertson, 2012). Aydoğdu (2017) laboratuvar ortamında kazaları önlemek için, kimyasal maddelerin özellikleri ile çalışma kurallarının 
öğrenilmesi gerektiğini vurgulamıştır. Atasoy (2004, s.72) öğrenme ortamındaki kuralların da öğrenme üzerinde etkili olduğunu belirtmiş̧tir. Öğretmen ve öğretmen adayları bu kurallara göre davranışlarını şekillendirir. Kuralların olmadı̆̆ 1 bir ortamda bireyler ne yapacaklarını bilemezler ve durum açıklığa kavuşuncaya kadar beklemek zorunda kalabilirler. Bu durum öğrencilerin öğrenme ortamına aktif katılımı konusunda problemlere yol açabilir. Hofstein ve Lunetta (1982), sınıf yönetiminde yaşanan sıkıntıların da öğretmenleri laboratuvar ortamında deney yapmaktan vazgeçirdiğini belirtmiş̧tir. Kuralların net olmaması ve öğrencilerin yabancı oldukları bu ortamda nasıl davranacaklarını bilmemeleri aktif katılıma engel olabileceği gibi sınıf yönetiminde yaşanan sıkıntılara zemin oluşturabilir. Deneylerin ve etkinliklerin etkili yapılması her şeyden önce laboratuvar kurallarına uyulmasına ve laboratuvar güvenliğinin sağlanmasına bağlıdır (Şenler, Karışan ve Bilican, 2017). Bu sebeple laboratuvara yön veren kuralların açık ve net olması gerektiği söylenebilir.

Fiziksel ortam boyutu, laboratuvarın fiziki altyapısı, içerisinde bulunan araç ve gereç sayısı ve diğer materyallerin amaca uygunluk derecesidir. $\mathrm{Bu}$ çalışmada, laboratuvar uygulamalarında yeterli alan olması, araç-gereçlerin düzenli çalışması, fiziksel ortamın uygun olması, araç gereçlerin amaca uygunluk derecesi "bazen" ve "çoğu zaman" düzeyindedir. Fiziksel ortam boyutu, Maurer (1985)'in grup gelişimi olarak tanımladığı uygulama aşaması ile ve Fraser vd. (1992)'nin geliştirdiği laboratuvar malzemeleri aşaması ile uyumlu olduğu söylenebilir. Laboratuvarlarda malzeme yetersizliği ve eksiliğine ilişkin sıkıntılarla karşılaşılması farklı araştırmalarda (Aydoğdu, 1999; Zion, Cohen ve Amir, 2007; Kocakülah ve Savaş, 2010) belirtilmiştir. Ayas vd., (2002) çalışmasında laboratuvarların hem araç-gereç ve malzeme yönünden hem de ideal bir ortam yönünden yeterli olmadığını, laboratuvar ortamında etkili öğrenmenin gerçekleştirilmesi için deneylerin kalabalık olmayan sınıf mevcuduyla ve 3-4 kişilik gruplarla yürütülmesini önermektedir. Çünkü kalabalık sınıflarda öğretmenin sınıfın bütününü kontrol altında tutması zorlaşacak, yeterli kontrol sağlanamadığı zaman öğrenme faaliyetlerinden sapmalar olabilmektedir (Öztürk, 2003). Bunun için laboratuvar ders saatlerinin artırılması, 5-6 kişiden oluşan grupların daha az kişiden oluşması gerektiği belirtilmiştir (Aydoğdu, 1999). Laboratuvarda deneyler için bireysel ya da grupsal çalışmalarda yeterli alan olması, araç-gereçlerin düzenli çalışması, fiziksel ortamın sıcak ve bunaltıcı olmaması gerekmektedir.

Türkiye'de bulunan 10 farklı devlet üniversitesinde öğrenim gören Fen Bilgisi öğretmen adaylarının Genel Kimya Laboratuvar çevresine yönelik algılarında üniversiteler arasında yakınlık, açık uçluluk, bütünleşme, kurallarda netlik ve fiziksel ortam boyutları açısından farklılık bulunmuştur. $\mathrm{Bu}$ çalışmadan elde edilen sonuçların literatürle uyumlu olduğu belirlenmiştir. Doğan vd., 2003'te farklı üniversitelerin Eğitim Fakültelerindeki Kimya Öğretmenliği Programlarında öğrenim gören birinci sınıf öğrencilerin içinde bulundukları Genel Kimya Laboratuvarı öğrenme çevresini nasıl algıladıklarını üniversite değişkeni açısından değerlendirilmiş ve üniversiteler arasında farklılık bulmuştur. Benzer şekilde Köse ve Küçükoğlu (2009), Eğitim Fakültelerindeki çalışmasında, sınıf öğrenme çevresinde öğretmen adaylarının öğrenim gördüğü üniversiteye göre farklılıklar bulmuştur. Fakülteler arasındaki her boyuttaki farklılıklar Genel Kimya Laboratuvarı dersine ilişkin fakülteler arasında bir standardın olmadığını göstermektedir. Aslında son 5 yıl içinde fakülteler Avrupa Birliğine uyum çerçevesinde ders içeriklerini standart hale getirmek için bilgi paketleri hazırlamışlardır. Ancak uygulamanın bu paketlerde belirtilen içeriklerle ne kadar uyumlu olduğu sınıflarda yapılacak gözlemlerle ortaya çıkarılabilir.

Öğretim elemanının Kimya ve Kimya/Fen Eğitimi uzmanlık alanına göre yakınlık, kurallarda netlik ve fiziksel ortam boyutlarında istatistiksel olarak anlamlı farklılık 
bulunmamıştır (Yakınlık p>0.05; Kurallarda Netlik p>0.05; Fiziksel Ortam p>0.05). Bu da öğretim görevlilerinin uzmanlık alanına göre bu boyutlarda Fen Bilgisi öğretmen adaylarının Genel Kimya Laboratuvar çevresine yönelik algılarında farklılık göstermiyorken, açık uçluluk $(\mathrm{p}<0.05)$ ve bütünleşme $(\mathrm{p}<0.05)$ boyutunda farklılık göstermektedir. Açık uçluluk boyutunda eğitim lehine, bütünleşme boyutunda ise kimya lehine anlamlı farklılık bulunmuştur. Bu sonuçlara göre, öğretim elemanının uzmanlık alanı Kimya/Fen Eğitimi olduğunda Genel Kimya laboratuvarı derslerinde öğrenciye laboratuvarda çalışma esnekliği sağladığı; yani her öğrencisini aynı deneyi yapmaya zorlamaması, her öğrenciye istediğinde farklı deney yapabilme şansını tanımasına daha çok dikkat ettiğini, uzmanlık alanı Kimya olan öğretim görevlilerinin ise teorik dersleriyle laboratuvar derslerinin paralel gitmesine daha çok dikkat ettiği söylenebilir. Öğretmenlerin laboratuvar uygulamalarına yönelik inançları ve tutumları, laboratuvar uygulamalarını etkilemektedir (Brown, Abell, Demir ve Schmidt, 2006; Cheung, 2007). Öğretmenler açık uçlu deney uygulamalarında kendilerini daha çok sorumlu hissetmekte (Welch, Klopfer, Aikenhead ve Robinson, 1981; Roehrig ve Luft, 2004) ve bazıları bilimi öğrenciye aktarılması gereken nesnel bilgiler bütünü olarak görmektedir. Bu durumda bilimin sadece öğretmen tarafindan öğretilebileceği, bunun da öğrencilerin öğretmenlerin direktiflerini yerine getirmesiyle gerçekleşeceği vurgulanmıştır (Cheung, 2007). Laboratuvarda öğrenmeye ilişkin öğretmenlerin buna benzer inançlara sahip olmalarının nedeni öğrencilerin yeterince motivasyona ve beceriye sahip olmadıkları görüşünü benimsemeleridir (Brown ve diğ., 2006; Cheung, 2007). Programda yer alan etkinliklerin etkili şekilde uygulanabilmesi için de okulun ve sınıfın fiziki şartlarının (sınıf mevcudu, oturma düzeni, kimya laboratuvarı vb.) yenilenen programa göre düzenlenmesi ve ders materyallerinin de yeterli düzeyde olması gerekmektedir (İşman, Baytekin, Balkan, Horzum ve Kıyıc1, 2002). Programı anlamayan, uygulamada yetersiz olan öğretmenler ve yetersiz fiziki koşullar yenilenen programın sağlıklı uygulanmasını etkileyecektir.

\section{Araştırmanın Sınırlılığı}

Bu çalışmada evrenin sadece \% 13'üne ulaşılmış olması, laboratuvar algılarının sadece Moos ve Trickett (1987) tarafindan oluşturulan algılarla belirlenmiş olması ve algıların belirlenmesinde sadece bir ölçeğin veri toplama aracı olarak kullanılması çalışmanın sinırlılıkları arasında belirtilebilir.

\section{6. Öneriler}

Fen Bilgisi öğretmen adaylarının Genel Kimya Laboratuvar çevresine yönelik algıları 2, 3, ve 4. sınıfta da incelenmelidir. Laboratuvarların araç-gereç ve kimyasal malzeme eksikliği giderilmeli ve böylece tüm grupların aynı deneyi yapması sağlanarak laboratuvar uygulamaları ile teorik dersler paralel bir şekilde yürütülmelidir. Deney gruplarındaki öğrenci sayısı düşürülerek öğrencilerin deneyleri bizzat kendilerinin yapmaları sağlanmalıdır. Laboratuvar ders saatleri artırılmalıdır. Laboratuvarda bulunan araç-gereçlerin gerekli durumlarda tamir, bakım ve onarımı için laboratuvar teknisyeni olmalıdır. Düzenli, temiz, aydınlık ve kimya konuları ile ilgili bilgileri içeren afiş-poster gibi materyallerle öğrencileri motive edici bir laboratuvar ortamı oluşturulmalıdır. Laboratuvarlarda öğrenciyi etkin kılarak, düzenli ve belli kurallara göre öğrenme ortamları hazırlayarak, öğrencilerin birbirlerine yönelik iyi ilişkiler kurmasını, olumlu ve demokratik sınıf çevrelerinin oluşturulmasına özen gösterilmesi gerektiği söylenebilir. 


\section{Kaynakça}

AYAS, A. (1998). Fen bilgisi öğretiminde laboratuvar kullanımı. Yaşar, Ş. (Editör). Fen bilgisi öğretimi. Eskişehir: Anadolu Üniversitesi Açıköğretim Fakültesi Yayınları, ss.99-113.

ATASOY, B. (2004). Fen ögrenimi ve öğretimi. Asil Yayın Dağıtım. Kızılay, Ankara.

AÇIKGÖZ, K.Ü. (2000). Etkili ögrenme ve öğretme. İzmir.

ANDERMAN, E.M. ve MAEHR, M.L. (1994). Motivation and schooling in the middle grades. Rewiev of Educational Research, 64, 287-309.

AMES, C. (1990). Motivation:What teachers need to know. Teachers College Record,91,409-421.

ATASOY, B. (2004). Fen öğrenimi ve ögretimi. Asil Yayın Dağıtım.

AYAS, A., AKDENIZ, A.R. ve ÇEPNİ, S. (1994). Fen bilimlerinde laboratuvarın yeri ve önemi-I. Çağdaş Eğitim Dergisi. 204, 21-25.

AYAS, A., ÖZMEN, H., KARAMUSTAFAOĞLU, S. ve SEVIM, S. (2002). Kimya Öğretmen Adaylarının Temel Kimya Kavramlarını Anlama Seviyelerinin Belirlenmesi. Karadeniz Teknik Üniversitesi. Fatih Eğitim Fakültesi.

AYDOĞDU, C. (1999). Kimya laboratuvar uygulamalarında karşılaşılan güçlüklerin saptanması. H.Ü. Ë̆itim Fakültesi Dergisi, 15,30-35.

AYDOĞDU, C. (2017). The Effect of Chemistry Laboratory Activities on Students' Chemistry Perception and Laboratory Anxiety Levels. International Journal of Progressive Education. Volume 13, Number 2.

BANDURA, A. (1986). The explanatory and predictive scope of self-efficacy theory. Journal of social and clinical psychology. 4: 359-373.

BÜYÜKEKŞİ, C. ve YAVUZ, S. (2015). Fen Bilgisi Öğretmen Adaylarının Kimya Algılarının İncelenmesi. Bülent Ecevit Üniversitesi, Ereğli Eğitim Fakültesi, OFMAE Bölümü, Kimya Eğitimi Anabilim Dalı. JOTCSC, Cilt: 1, Sayı: 1, 107-118.

BOUD, D., DUNN, J. ve HEGARTY-HAZEL, E. (1986). Teaching in Laboratories. Guildford, Surrey: SRHE and NFER-Nelson.

BOOTH, G. (2001). Is inquiry the answer? Science Teacher, 68: 57-59.

BROWN, P.L., ABELL, S.K., DEMIR, A. ve SCHMIDT, F.J. (2006). College science teachers' views of classroom inquiry, Science Education, 90, 784-802.

BÖYÜK, U., DEMIR, S. ve EROL, M. (2010). Fen ve teknoloji dersi öğretmenlerinin laboratuvar çalışmalarına yönelik yeterlik görüşlerinin farklı değişkenlere göre incelenmesi. Tubav Bilim Dergisi, 3: 342-349.

CHEUNG, D. (2007). Facilitating chemistry teachers to implement inquiry-based laboratory work, International Journal of Science and Mathematics Education, 6(1), 107-130. 
CHEUNG, H.Y. (2008). Teacher efficacy: A comparative study of Hongkong and Shanghai primary inservice teachers. The Australian Educational Researcher, 35: 103-123.

ÇALLICA, H., EROL, M., SEZGIN, G. ve KAVCAR, N. (2001). İlköğretim kurumlarında laboratuvar kullanımına ilişkin bir çalışma. IV. Fen Bilimleri Kongresi. Ankara: MEB. Basimevi.

ÇOŞTU, B., ÜNAL, S. ve AYAS, A. (2007). Günlük yaşamdaki olayların fen bilimleri öğretiminde kullanılması. Ahi Evran Üniversitesi Kırşehir Eğitim Fakültesi Dergisi (KEFAD), Cilt 8, Sayı 1:197-207.

DETERS, K. M. (2005). Student opinions regarding inquiry-based chemistry experiments. Hong Kong: Goverment Logistics Department.

DI GIULLIO, R. (2006). Positive classroom management: A step-by-step guide to helping students succeed. Thousand Oaks, CA:Corwin.

DOĞAN, D., DOĞAN, E., ATILGAN, H., BATÇIOĞLU, K. ve DEMIRCI, B. (2002). Farklı Üniversitelerin Eğitim Fakültelerindeki Genel Kimya Laboratuvarı Sınıf Çevresinin Bazı Değişkenler Açısından Değerlendirilmesi, V. Ulusal Fen Bilimleri ve Matematik Eğitimi Kongresi, Ankara.

DOĞAN, D., ATILGAN, H. ve DEMİRCI, B. (2003). Genel kimya laboratuvarı sınıf çevresi ölçeği-gerçek formunun uyarlama çalışması. Ĕgitim Araştırmaları, 4(12), 56-63.

DOMIN, D. S. (2007), Students' perceptions of when conceptual development occurs during laboratory instruction, Chemistry Education Research and Practice, 8(2), 140-152.

DURU, M.K., DEMIR, S., ÖNEN, F. ve BENZER, E. (2011). Sorgulamaya Dayal1 Laboratuvar Uygulamalarının Öğretmen Adaylarının Laboratuvar Algısına Tutumuna Ve Bilimsel Süreç Becerilerine Etkisi. M.Ü. Atatürk Eğitim Fakültesi Ĕgitim Bilimleri Dergisi., 33: 25-44.

EMMER, E. ve EVERTSON, C. (2012). Classroom management for middle and high school teachers (th ed.). Upper Saddle River, NJ:Pearson/Merrill.

ENTWISTLE, N. (1998). Improving teaching through research on student learning. In J. J. F. Forest (Ed.), University teaching: International perspectives (pp. 73-112). New York: Garland Publishing.

ERGIN, Ö., YILDIZ E. ve AKPINAR, E. (2005). XIV.Ulusal Eğitim Bilimleri Kongresi Sözlü Bildiri. 28-30 Eylül. Denizli.

FEYZİĞLU, B., DEMIRDAĞ, B., ATEŞ, A., ÇOBANOĞLU, İ., ve ALTUN, E. (2011). Kimya Öğretmenlerinin Laboratuvar Uygulamalarına Yönelik Algıları: İzmir İli Örneği. Kuram ve Uygulamada Eğitim Bilimleri. Educational Sciences: Theory ve Practice - 11(2). 1005-1029. 
FRAENKEL, J. R. ve WALLEN, N. E. (2000). How to Design and Evaluate Research in Education. New York: McGraw-Hill.

FRASER, B.J., GIDDINGS, G. ve MCROBBIEE, C. (1992). Assessment of the psychosocial environment of university science laboratory classrooms: A cross-national study. Higher Education, 24, 431-451.

FRASER, B. J. (1994). Research on Classroom and school climate. In D: Gabel (Ed.), Handbook of research on science teaching and learning. New York: Macmillan, s. 493-541

GÜNEŞ, M. H., ŞENER, N., GERMİ N.T. ve CAN, N. (2013). Fen Ve Teknoloji Dersinde Laboratuvar Kullanımına Yönelik Öğretmen Ve Öğrenci Değerlendirmeleri. Dicle Üniversitesi Ziya Gökalp Eğitim Fakültesi Dergisi, 20: 1-11.

HAERTEL, G.D., WALDBERG, H. J. ve HAERTEL E.H. (1981) Socio-psychological environments and learning: A quantitative synthesis. British Educational Research Journal, 7, 27-36.

HEGARTY-HAZEL, E. (Ed.) (1990). The Student Laboratory and the Science Curriculum. London: Routledge.

HEIN, E. G. (1991). Constructivist Learning Theory. CECA (International Committee of Museum Educators) Conference Jerusalem Israel. 5-22, October.

HOFSTEIN, A., LEVİ-NAHUM, T. ve SHORE, R. (2001). Assessment of the learning environment of inquiry-type laboratories in high school chemistry. Learning Environments Research, 4, 193-207.

HOFSTEIN, A., SHORE, R. ve KIPNIS, M. (2004). Providing high school chemistry students with opportunities to develop learning skills in an inquiry-type laboratory: A case study. International Journal of Science Education, 26, 47-62.

HOFSTEIN, A. ve LUNETTA, N. V. (1982). The role of the laboratory in science teaching: Neglected aspect of research. Review of Educational Research, 52: 201-217.

İSMAN, A., BAYTEKIN, Ç., BALKAN, F., HORZUM, B. ve KIYICI, M. (2002). Fen Bilgisi Eğitimi Ve Yapısalcı Yaklaşım. The Turkish Online Journal of Educational Technology, 1(1).

JACOBS, E., POWER, M. ve LOH, W. (2002). Teacher's source book for cooperative learning. Thousand Oaks, CA:Corwin.

KANLI, U. (2007). 7E Modeli Merkezli Laboratuvar ile Doğrulama Laboratuvar Yaklaşımlarının Öğrencilerin Bilimsel Süreç Becerilerinin Gelişimine ve Kavramsal Başarılarına Etkisinin Karşılaştırılması. Yayımlanmamış Doktora Tezi, Gazi Üniversitesi, Eğitim Bilimleri Enstitüsü. Ankara. 
KINGIiR, S., TAS, Y., GOK, G. ve VURAL, S. S. (2013). Relationships among constructivist learning environment perceptions, motivational beliefs, self-regulation and science achievement. Research in Science ve Technological Education, 31: 205226.

KOCAKÜLAH, A. ve SAVAŞ, E. (2010). Fen Bilgisi Öğretmen Adaylarının Deney Tasarlama ve Uygulama Sürecine İlişkin Görüşleri. Ondokuz Mayıs Üniversitesi Eğitim Fakültesi Dergisi 2011, 30(1), 1-28.

KOZMA, R., CHIN, E., RUSSELL, J. ve MARX, N. (2000). The role of representations and tools in the chemistry laboratory and their implications for chemistry learning. Journal of the Learning Sciences, 9(3), 105-144.

KÖSE, E. ve KÜÇÜKOĞLU, A. (2009). Eğitim Fakültelerindeki Sınıf Öğrenme Çevresinin Bazı Değiskenler Açısından Değerlendirilmesi. Ahi Evran Üniversitesi. Ĕ̆itim Fakültesi Dergisi. Cilt 10, Sayı 3. Sayfa 61-73.

LAURA B. BUCK, STACEY LOWERY BRETZ, AND MARCY H. TOWNS (2008). Characterizing the Level of Inquiry in the Undergraduate Laboratory. Journal of College Science Teaching, Vol. 38, No. 1 (September/October 2008), pp. 52-58

LANDSMAN, A. ve LEWIS, C. (2011). White teachers/diverse classrooms: Creating inclusive schools, building on students' diversity, and providing true educational equity (2nd ed.) Sterling, VA: Stylus Publishing.

LUNETTA, V. N. (1998). The school science laboratory: Historical perspectives and contexts for contemporary teaching.

MAEHR, M.L. ve MINDGLEY, C. (1991). Enhancing student motivastion: A school wide approach. Educational Psychologist, 26, 399-427.

MAURER, R.E. (1985). Elementary discipline handbook: Solutions for the K-8 teacher. West Nyack, NY: The Center for Applied Research in Education.

MOOS, R. H. ve TRICKETT, E. J. (1987). Classroom environment scale manual (2nd ed.). Palo Alto, CA: Consulting Psychologists Press.

ROEHRIG, G.H. ve LUFT, J.A. (2004). Constraints experienced by beginning secondary science teachers in implementing scientific inquiry lessons. International Journal of Science Education, 26 (1), 324.

SUCUOĞLU, H. (2017), İş birlikli öğrenme ve iş birliği süreci, Etkili ögrretim yöntemleri araştırma temelli uygulama, ACAT, M.B. (Translation Editor), BORICH, G.D. (Eds.), İstanbul, Nobel Yayınc1lık, s.352-377.

SÖNMEZ, V. (2012). Program geliştirmede öğretmen el kitabı. Ankara: Anı Yayıncılık. 17.bask1. 
ŞENLER, B., KARIŞAN, D. ve BİLİCAN, K. (2017). Sınıf Öğretmeni Adaylarının Fen ve Teknoloji Laboratuvarına Yönelik Alg1 ve Tutumlarının İncelenmesi. Mehmet Akif Ersoy Üniversitesi Eğitim Fakültesi Dergisi. Sayl: 42, Sayfa: 105-122.

ÖZTÜRK, B. (2003). Sinıfta İstenmeyen Davranışların Önlenmesi ve Giderilmesi, Sinıf Yönetimi İçinde. Pegem Akademi: Ankara.

UÇAR, E. ve YEŞiLYAPRAK, B. (2006). Öğrenmeden Öğretime. Eğitim Psikolojisi. Pegem Yayınc1lık: Ankara.

WELCH, W.W., KLOPFER, L.E., AIKENHEAD, G.S. ve ROBINSON, J.T. (1981). The role of inquiry in science education: Analysis and recommendations. Science Education, 65, 33-50.

ZION, M., COHEN, S. ve AMIR, R. (2007). The spectrum of dynamic inquiry teaching practice. Research in Science Education, 37(4), 423-447. 